\title{
TTR
}

Traduction, terminologie, re?daction

\section{Der Proce $\beta$ in Yiddish, or The Importance of being Humorous}

\section{Iris Bruce}

Volume 7, numéro 2, 2e semestre 1994

Traduire les sociolectes

URI : https://id.erudit.org/iderudit/037180ar

DOI : https://doi.org/10.7202/037180ar

Aller au sommaire du numéro

\section{Éditeur(s)}

Association canadienne de traductologie

\section{ISSN}

0835-8443 (imprimé)

1708-2188 (numérique)

Découvrir la revue

\section{Citer cet article}

Bruce, I. (1994). Der Proce $\beta$ in Yiddish, or The Importance of being Humorous. TTR, 7(2), 35-62. https://doi.org/10.7202/037180ar

\section{Résumé de l'article}

Le Procès en yiddish ou l'importance d'être humoristique - L'auteure met en lumière le Kafka humoristique - et non kafkaesqu - et critique le « mythe Kafka » qui s'est constitué après la Seconde Guerre mondiale, centré surtout sur l'angoisse existentielle chez Kafka. Bien avant la guerre, Max Brod ainsi que Walter Benjamin reconnurent la dimension humoristique des textes de Kafka, dont l'essentiel se trouve dans les jeux de mots et les gestes; en dehors de ces auteurs, l'humour chez Kafka restait inaperçu. Le présent article met l'accent sur les contextes culturels et idéologiques anglais, allemand et yiddish qui ont déterminé des lectures/traductions disparates de ses textes. L'article établit surtout une comparaison entre la traduction d'avant-guerre du Procès par Edwin et Willa Muir, qui contribua au « mythe Kafka », et la traduction yiddish d'après-guerre de Melech Ravitch, laquelle souligna les qualités humoristiques du roman. D'une part, la traduction yiddish situe le roman de Kafka dans un genre littéraire qui est culturellement spécifique en même temps qu'elle suggère une lecture « juive » alternative du texte; mais, d'autre part, se fondant sur la traduction anglaise et la version allemande originale, Ravitsch " corrige » aussi le " mythe » du Kafka angoissé et constitue un défi au genre assez morne du kafkaesque qui demeure si répandu dans les cultures de langue anglaise et allemande contemporaines.
Tous droits réservés ( $\mathrm{C}$ TTR: traduction, terminologie, rédaction - Les auteurs, Ce document est protégé par la loi sur le droit d’auteur. L’utilisation des 1994 services d'Érudit (y compris la reproduction) est assujettie à sa politique d'utilisation que vous pouvez consulter en ligne.

https://apropos.erudit.org/fr/usagers/politique-dutilisation/ 


\section{Der Proceß in Yiddish, or The Importance of being Humorous}

\section{Iris Bruce}

Dear Uncle Jack is so very serious! Sometimes he is so serious that I think he cannot be quite well.

Oscar Wilde, The Importance of Being Earnest

\section{Introduction'}

In the past, many interpretations of Franz Kafka's writings have stressed their psychological, religious, existential and moral dimensions and initiated a whole genre of the kafkaesque which conjures up associations of the grotesque and absurd but is rarely associated with a sense of humour. Kafka's very "name has become a part of the language - a 'Kafkaesque,' or Kafka-like situation being one of a strange or nightmarish quality" (Crawford, p. 3). Generally, after World War II (and largely due to the prominence of New Criticism and Existentialism in the literary academies during this time), a Kafka myth has cristallized which emphasizes Kafka's existential anguish: interpretations, be they religious, phenomenological, existentialist, symbolic or allegorical, center on the psychology of the author, who is presented as being overcome by the sense of absurdity and alienation so prevalent in twentieth

1. An early version of this paper was presented at the Translation Studies Congress, "Translation Studies: An Interdiscipline," Vienna, Austria (1992). 
century culture. ${ }^{2}$ Where this metaphysical approach in literary interpretation as a discipline has been most detrimental is in its emphasis on the "universal" rather than on specific textual elements, in the obsession with Kafka's personal neuroses, in the mingling of psychological speculation and literary criticism which frequently led to a "false confusion of empirical and literary selves" (Corngold, 1977, p. 69), and most importantly in its overall disregard of the playful and humorous dimension in Kafka's texts.

Translations of Kafka's works have done their share in spreading the "serious Kafka" myth. In the English speaking world, the translations of Edwin Muir ${ }^{3}$ are said to have "einem Jahrzehnt der Kafka-Interpretation in England die Richtung gewiesen" [paved the way for a decade of Kafka interpretation] (Jakob, p. 103). These translations are a product of the European cultural and intellectual milieu of the nineteen-thirties. Yet, their effect in English speaking countries has reached far into the post-war period. For instance, Orson Welles' 1963 film The Trial is greatly indebted to the anguished, expressionistic genre of the kafkaesque. And that the fabricated "Kafka myth" is still very much alive is evident in a recent British play by Arnold Bennett, Kafka's Dick (1987): even though this play pokes fun at the psychologizing orientation of Kafka scholarship, it is still indebted to the picture of "Kafka the neurotic" who succumbs to his anguish in the face of the absurdity of life, a representation which cannot be supported by biographical evidence.

In view of the many "serious" readings of Kafka, I would like to draw attention to a counter-translation, the 1966 translation

2. For example, see Crawford (1973), Demmer (1973), Emrich (1958), Friedman (1967), Golomb (1985), Goodman (1947), Heidsieck (1983), Robert (1979), Schoeps (1951), Tiefenbrun (1973).

3. Since the translator's wife, Willa Muir, worked on these translations together with her husband, I will in the following refer to "the Muirs." 
of Der Proce $\beta$ into Yiddish, by the Yiddish poet Melech Ravitch (a pseudonym for Zekharye Khone Bergner [1893-1976]). ${ }^{4}$ Ravitch draws on both the English translation (by Edwin and Willa Muir) and the German original, but he "corrects" the anguished, expressionistic Kafka myth by staying as close to the German source text as possible. More importantly even, Ravitch's Yiddish translation - along with the drawings which accompany the text (by Ravitch's son, the Israeli painter Yossl Bergner [1920- ]) - is significant, because it constitutes a challenge to the rather humourless genre of the kafkaesque so widespread still in contemporary English and German speaking cultures ${ }^{5}$.

\section{Ravitch and the Muirs' Ideology}

The title page of the Yiddish translation makes mention of both the German title and the title of the English translation. Closer examination reveals that the English translation functioned as an intertext, i.e. in the sense of an interpretant. The German source text

4. I came across this translation in an article written in Yiddish by Zilbertsvayg (1968). Ravitch's translation is not listed in Binder (1979): see pp. 595-599, 624-785, nor is it mentioned in the Encyclopaedia Judaica, 13 (1971) under Melech Ravitch. I wish to thank Régine Robin for initially pointing out to me that the translator is identical with the Yiddish poet. Ravitch was born in Radymno, Galicia, came to Vienna in 1913 and served in the Austrian army during World War I. In 1921 he went to Warsaw and began publishing Yiddish expressionist magazines. He travelled around the world and settled in Montreal in 1941, where he lived until his death in 1976. For further information on Ravitch see: Madison (1968), pp. 320-321; Whitman (1979), pp. 103-107, 141; Howe (1987), pp. 301-317. For Yoss1 Bergner see: Encyclopaedia Judaica, 4 (1971).

5. An exception to this is the recently published book by David Zane Mairowitz and Robert Crumb, Kafka for Beginners (Icon Books, 1993), which came to my attention too late to be considered in this context. 
was consulted throughout and as a result numerous inaccuracies and imprecise formulations in the English translation are "corrected" and brought closer to the German original. These "corrections" counter the Muirs' anguished and metaphysical reading of Kafka's text.

For one, the English translation of Der Proceß highlights the metaphysical anguish of the protagonist Josef $\mathrm{K}$., whose explanation in the original German,

Es kommt auf viele Feinheiten an, in denen sich das Gericht verliert. Zum Schluß aber zieht es von irgendwoher wo ursprünglich gar nichts gewesen ist, eine große Schuld hervor (p. 200) [It depends on many subtleties in which the court loses itself. In the end, though, it draws out a serious perpetration from somewhere where there was nothing before $]^{6}$

is too laconic for the Muirs who change the meaning of this sentence to

I have to fight against countless subtleties in which the Court indulges. And in the end, out of nothing at all, an enormous fabric of guilt will be conjured up (p. 149)

The translators have shifted the emphasis away from the Court to Josef K., who is now represented as a fighter against the "countless subtleties in which the Court indulges" (p. 149; my emphasis), subjecting himself to the whims of the court (suggested by the word "indulges") and thus combatting forces beyond his control. Moreover, the moral, philosophical and existential dimension inherent in the German "eine große Schuld" [a serious perpetration] is expanded into "an enormous fabric of guilt" (p. 149). In contrast, the Yiddish translator decides on the less dramatic "a groyse

6. Unless indicated otherwise, all translations from the German, as well as the Yiddish, are my own. Translations from the Yiddish appear in transliteration according to the YIVO style of transcription. 
shuldikeyt"[a serious perpetration] (pp. 150-51) and thereby reestablishes the laconic nature of the German original.

Second, not only does the English translation overemphasize K.'s existential anguish, but it frequently uses vocabulary that has religious overtones and thus reveals a further ideological orientation. For instance, the formulation "it sounded like a prayer, not like a summons" (p. 23) is not in the source text, where the equivalent word for "prayer" is "eine Bitte" [a request, an entreaty]: "es klang wie eine Bitte, nicht wie ein Anruf" (p. 39). In addition, Kafka clearly counters the religious connotations that can be read into the word "Anruf" [call, challenge], such as "invocation," by insisting that this call sounded like a "Bitte," which has no religious connotations. The Muirs ignore Kafka's denial of the religious associations and reclaim a religious dimension for this sentence, thus fundamentally changing its meaning for an English reader. The Yiddish translation, on the other hand, again translates literally and reestablishes the non-religious context, "es hot geklungen vi a betn zikh un nisht vi a ruf" (p. 36) [it sounded like an entreaty and not like a call].

Another example is the description of a statue by Titorelli which may have implicit religious overtones in the original since the light surrounding the statue's head is described as "strahlenförmig", "wie ein Schmuck" (p. 197). The English translation makes explicit the possible religious connotations in "strahlenförmig" (which suggests beams of light emanating from a star) by employing the word "halo": "[...] a shadow which tapered off in long rays-like a halo" (p. 147). However, once again Kafka's formulation plays with the religious association only to dismiss it. Instead of using the German word for "halo" - i.e. "Heiligenschein" - which would have strengthened the religious semantic field, Kafka obviously chose not to and decided to employ the neutral term "Schmuck" [decoration, jewelry]. As for the Yiddish translation, again the translator decides against the English "halo" and renders the phrase without the religious connotations as "vi a tsirung" (p. 148) [a decoration]. 
The above examples reveal the Muirs' ideological motivations behind their "religious/metaphysical allegory" (Jakob, p. 107) which makes existential or religious references that are implicit in Kafka explicit in the English translation and even adds connotations that do not exist in the original. However, while the Muirs frequently see religious connotations where there are none, sometimes they miss religious connotations that are clearly there, because they are not familiar with them in the source text. Thus, the translators miss entirely the meaning of "das ewige Licht" (p. 281) [the "perpetual light"] and translate it as "the light from a permanent oil lamp" (p. 205). The result is a total confusion of references in the whole paragraph, where torch and oil lamp are continually mixed up. The Muirs' metaphysical-religious orientation, as well as their lack of awareness of some of the religious connotations in the source text show the limits of the translator who cannot escape his/her own cultural domain and whose overall interpretation of the author's work negatively affects particular translations.

\section{Ravitch's Ideology}

The reader of Ravitch's Yiddish translation of Kafka is no less confronted with matters of ideology. Clearly, and more so than with the English translation, the very choice of the target language is ideologically motivated. Translating into Yiddish after World War II meant translating for a very small market, and as a matter of fact only one thousand copies of the book were published. Thus, the question arises, why would Ravitch undertake this translation as late as 1966 Yiddish speaking immigrants could have just as well read Kafka in Polish, Russian, Hungarian, English, etc. Translating Kafka into Yiddish, the language of a "minor literature," is a personal as well as a political and ideological statement.

This is indicated already by the "frame" which surrounds the Yiddish translation: a foreword which appears to be by Kafka's

7. See Deleuze and Guattari (1986), "What Is a Minor Literature?" (pp. 16-27) 
friend Max Brod, and an afterword on Kafka's life and work by Melech Ravitch. Most of the foreword seems to have been taken from Brod's biography of Kafka, which stresses Kafka's proximity to his Jewish heritage. For instance, Brod mentions Kafka's time at the liberal Rabbinic Institute in Berlin, the "Hochschule für die Wissenschaft des Judentums," in 1923/24 and describes it as follows:

\begin{abstract}
Er hört in der Präparandie Professor Torczyner und Professor Guttmans Vorträge über den Talmud. Er liest leichtere hebräische Texte. Nur dieser Kurse wegen kommt er regelmäßig aus dem stillen Vorort nach Berlin (p. 176) [He attends professor Torcyner and professor Guttman's lectures on the Talmud in the preparatory class. He reads Hebrew texts which are not too difficult. It is only because of these courses that he regularly leaves his quiet home on the outskirts of the city and comes to the inner city].
\end{abstract}

Brod's account is slightly exaggerated because it almost sounds as if Kafka took courses from professors Torczyner and Guttman, which was not the case. Kafka did, however, take preparatory courses at the "Hochschule" (together with his companion Dora Diamant), which introduced students to rabbinic texts and gave instruction in biblical Hebrew. ${ }^{8}$ Lectures by Torcyner and Guttman may very well have been planned into these courses. What is interesting now is that the account in the foreword to Ravitch's

8. According to Dora Diamant, she attended the Halakha section of the course, while Kafka went to the Aggadah section, and she recalls that Kafka treated the aggadic legends like Grimm fairy tales: "Pendant qu'elle fréquentait les cours du Talmud partie Halakha (les Lois), Kafka consacrait son temps à la partie Hagadah (les Légendes) [...]. Il prisait ses histoires comme si c'était les contes de Grimm" (Baudy, 1950, p. 22). Kafka stresses that he was in the "Präparandie," i.e. he was taking preparatory courses: "Freilich bin ich kein ordentlicher Hörer, bin nur in der Präparandie und dort nur bei einem Lehrer und bei diesem nur wenig [...]." (Briefe 470) [Of course, I am not a regular student, am taking only preparatory courses and there I am only with one teacher and not too frequently either [...].] 
translation (a foreword which is explicitly attributed to Max Brod) further exaggerates Kafka's attendance of these lectures:

[...] azoy lang vi di letste koyekh hobn im getrogn in letstn yor fun zayn lebn, flegt er pinktlekh araynkumen in der institut fun yidishe limudim in Berlin [...] er is geven oyf ale lektsies fun profesor Tortshiner un oykh profesor Gutman. di lektsies zenen geven araynfirn in dem yam-Talmud. er hot zikh bamit aleyn tsu leyenen gringere hebreishe un aramishe textn (p. 11). [as long as his strength lasted in these last years of his life, he would arrive on time in the rabbinic institute in Berlin [...] he went to all lectures by professor Torcyner and also by professor Gutman. The lectures were introductions to the Talmud. He attempted to read Hebrew and Aramaic texts which were not too hard; my emphasis].

In view of the increased embellishment of Brod's original version, it is questionable whether this Yiddish foreword was indeed written by Brod, even though it is signed "Max Brod" (p. 13). If it was, it must have been translated (and interpreted) by Ravitch, because Brod could not write in Yiddish. What is equally possible, though, is that Ravitch translated bits and pieces from Brod's Kafka biography, combined them with his own commentary and then ascribed the foreword to Brod. Either way, Ravitch's own ideological motivations seem to match those of Brod who argues for a religious interpretation of Kafka's work and claims that Kafka is indeed a very "Jewish" writer even though the word "Jew" does not appear in any of his literary texts.

Ravitch's own afterword is equally ideological. There is no commentary whatsoever on his technique of translation. His main concern is with Kafka's life. Like Brod, Ravitch stresses Kafka's growing interest in Judaism:

er hot zikh genumen lernen hebreish, gelernt khumesh, rashi, afile arayngekukt in a blat gmore, un gor shtark zikh farinteresirt mit loshn yidish (p. 237) [he began to study Hebrew, the Pentateuch, Rashi, even tried to read the Gemara, and was very interested in Yiddish]. 
This account is generally correct; what is disconcerting about Ravitch's biographical overview, though, is that many of the dates of Kafka's life are either wrong or jumbled. It does not seem to matter that Kafka's friendship with the Yiddish actor Ytzhak Löwy occurred as early as 1911: Ravitch places it towards the end of Kafka's life where it serves as a transition for his account of Kafka's life with the Yiddish-speaking Dora Diamant (p. 237). Moreover, Kafka's and Dora's meeting (which is erroneously said to have taken place in Berlin [p. 237]) is described as follows: "[...] zenen zey bayde tsugefaln tsu zikh un zikh fareynikt vi tsvey flamen un gevorn eyns bis Kafkas [...] sof" (pp. 237-38) [they both fell in love with each other and came together like two flames and became one until Kafka's death]. Ravitch resorts to sentimentality when he suggests that Dora gave Kafka the peace he needed by singing Yiddish songs to him: "Dora Diamant hot Frants Kafka - vi an umheylbar krankn yingl - arayngevigt un arayngezungen in der eybiker ru arayn" (p. 238) [Dora Diamant rocked Franz Kafka like a very ill child and sang lullibies for him until he died]. Furthermore, it is in keeping with Ravitch's account that Kafka's works are described not in analytic but in expressionistic vocabulary as "komplitsirte vi rizike knoyln mit elektrish ongelodene drotn" (p. 238) [complex and gigantic clusters with electrically charged wires] and also as "verk, vos zenen di anung, di varenung, di kosmishe shrek far der onkumendikn tsvantsikstn yorhundert mit zayne milkhomes [...]" (p. 238) [texts which carry the premonition, the warning, the cosmic fear of the approaching twentieth century with its wars]. One can see Ravitch's expressionistic orientation: he was little concerned with getting literary-historical facts right; nor indeed does he seem to have been greatly concerned with particular strategies adopted in his translation.

\section{The Translation: "Maximum Clarity"}

Indeed, it may come as a surprise after witnessing the ideological and expressionistic orientation in the foreword and the biographical afterword, and Ravitch's lack of attention to literary-historical factual knowledge, that the ideological frame stands in stark contrast to the translation itself which reproduces the German source text as 
closely as possible. There are several viable reasons to explain this contrast. According to the Encyclopaedia Judaica, Ravitch retreated from expressionism in the late thirties and underwent a radical turn: "Instead of trying to shock and mystify his readers, he aimed at maximum clarity. He proclaimed himself a citizen of the world, a poet beyond nationalism" (p. 1586). Perhaps his afterword was written in the thirties; perhaps Ravitch simply embellished excerpts from Brod's Kafka biography from the 1930s; in any event, there is no trace of expressionist vocabulary in his Yiddish translation.

In fact, we have already seen Ravitch's rather more "literal" orientation. Indeed he is so bent on being as literal as possible that he "corrects" the English translation even when formulations do not destroy the meaning of the German but are nonetheless not quite literal. For instance, K. excusing himself "for knocking so late" (p. 18 , my emphasis) is translated as "vos er kumt azoy shpet" [because he arrived so late] (p. 32, my emphasis), which is a literal translation of the German source text "daß er so spät komme" (p. 32 , my emphasis). Ironically, the desire for a literal translation is so strong that at one point it even leads to an overcorrection. In Joseph $\mathrm{K}$.'s encounter with a hunchback and her sisters, the German refers to the sisters as "Geschwister" (p. 193) which the English renders as "sisters" (p. 144). Since "Geschwister" is a neutral term, usually referring to both brothers and sisters, Ravitch replaces the English "sisters" with "briderlekh un shvesterlekh" (p. 145) [brothers and sisters]. However, Ravitch failed to see that the German source text in this case clearly refers to the hunchback's "sisters." Ravitch's desire for "literalness" here creates an ironic situation in which the translator corrects the supposedly incorrect English translation which was, however, quite appropriate.

\section{Minimizing Kafka's "Germanness"}

The question arises, since Ravitch's goal is to remain as close as possible to the German source text, then why is there no mention of such an obvious translation strategy Ravitch merely states in his afterword, "di verk zenen dershinen in daytsh, ober balt zenen zey gevorn der kinyen fun der gantser veltliteratur" (p. 239) [the works 
appeared in German but they soon became the (spiritual) property of all world literature]. And Ravitch ends by further stressing that Kafka's texts have been translated into many languages and have found scholarly attention in many cultures. It can be said here that Ravitch is arguing for a "universal" Kafka in order to justify his own "appropriation" of Kafka, returning him to "Jewishness" by translating him into a "minor" literature and thereby divorcing him from his "Germanness."

Ravitch's attempt (conscious or not) to divest one of the major writers in German literature of his "Germanness" can be placed within the larger cultural-historical context of the post-war period. One must consider here the uneasy German-Jewish relations after the Holocaust, and in particular the tendency in the German speaking world to "appropriate" German-Jewish writers as "German." In 1966, the same year the Yiddish translation was published, Gershom Scholem succinctly characterized the problematic when he mentioned the

offenkundige Scheu, Juden, die nicht unbedingt darauf bestehen, Juden zu nennen. [...] Nachdem sie als Juden ermordet worden sind, werden sie nun in einem posthumen Triumph zu Deutschen ernannt, deren Judentum zu betonen ein Zugeständnis an die antisemitischen Theorien wäre $(1967$, p. 23) [obvious uneasiness to refer to Jews as Jews when they do not expressly insist on this themselves [...] After they were murdered as Jews, they are now after the fact triumphantly turned into Germans; to call them Jewish would seem to be an acknowledgment of antisemitic theories].

Kafka was no exception. As late as 1987 , Ernst Pawel objected to the place Kafka had been given in German literature: "Aber als Gipfel der Ironie mag dabei eigentlich die Metamorphose des archetypischen Prager Juden $\mathrm{zu}$ einem Deutschen Klassiker erscheinen" (p. 253) [But the height of the irony is the metamorphosis of the archetypical Prague Jew into a German classic]. Even though the phrase "archetypische[r] Prager Jude[]" is rather exaggerated, Pawel's polemic confronted a sensitive issue head on. Translating Kafka into Yiddish, then, can be seen as a way 
of reclaiming him, of re-appropriating him, by reconstructing in Yiddish Kafka's "Jewishness" (little as there may be) which is in danger of disappearing again in the post-war period, first silenced by fascism and now by post-war ideology. The Yiddish translation is thus a form of cultural reappropriation: since Kafka's texts through translation are said to become the "spiritual property" ("der kinyen") of all literatures, Ravitch's Yiddishization of Der Proce $\beta$ also gives Kafka a place in Jewish culture.

\section{The Yiddishization of Der Proceß}

From the outset, the Yiddish translation creates a much lighter tone than exists in the German original, because Yiddish is per se much more chatty and colloquial than formal German. Thus, Yiddish syntax replaces High German, as in "vos zhe hob ikh geton - bin ikh gegangen tsu mayn advokat un ikh hob zikh baklogt" (p. 178) [what did I do then - I went to my lawyer and complained], in contrast to the German "Ich ging also zum Advokaten und beklagte mich" (p. 241) [then I went to the lawyer and complained]. Frequently, melodrama is added, as when the German "ich schäme mich ja so erbärmlich" (p. 113) [I am so terribly embarrassed] is transformed into the exclamation, "ikh shem zikh poshet, oy, vi ikh shem zikh" (p. 93) [I am so ashamed, oh, how ashamed I am!]. Other changes to Kafka's text include making the structure of the narrative more anecdotal: for instance, inserted background information is introduced by the phrase, "un es iz geven a bazundere sibe dertsu" (p. 97) [and there is a particular reason for this], an oral interjection which is not in Kafka's original German, but which highlights, in Yiddish, the anecdotal nature of the story which follows. In addition, fixed phrases are added frequently and form a kind of leitmotif, such as "vi di zakh zol nisht zayn" [lit.: as is not supposed to be] which replaces the German "trotz allem" [despite everything], "immerhin" [for all that], "jedenfalls" [at any event], "allerdings" [to be sure]. Many of these common phrases and expressions are reminiscent of oral literature and transform the formal language of Kafka's text into a more informal conversational style. Finally, the Yiddish translation adds Jewish cultural markers, as when a character's feet are described as "ayngedreyt in a beygl" 
(p. 69) [twisted like a bagel]. "Bagel" replaces the German "Kreis" (p. 90) [circle]. It is not that the word "Kreis" does not exist in Yiddish - in fact, the translator uses it later on in the text ("dreyen in dem kleynem krays" [p. 162; turning in the small circle]) - but here he opts for the more graphic illustration, a conscious attempt to anchor the text in a Jewish referential system. On the one hand, then, this Yiddishization of Kafka's text is no more than part of translating into the particular target culture. At the same time, though, the colloquialization of Kafka's text radically changes Kafka's original choice of language. It needs to be stressed here that Kafka, indeed, could have employed many of the numerous idiomatic expressions and phrases used in the Yiddish translation because they are also typical of colloquial German. ${ }^{9}$ However, Kafka consciously chose a more formal register in German.

\section{Re-establishing a Jewish Cultural Framework}

At the same time, there are many references and allusions to Jewish culture in Kafka's texts which have generally been missed by

9. Compare the following variants between the Yiddish and German in particular:

- "blitsshnel" (p. 80) - "äußerst schnell" (p. 107) - "with the utmost haste" (Muir, p. 73);

- "azoy is es dokh geshtanen shvarts oyf weys in dem rekomendatsie-brif" (p. 149, my emphasis) - "wie es ja auch in Ihrem Empfehlungsschreiben steht" (p. 198, Kafka could have but did not use the idiomatic expression "schwarz auf weiß" [in black and white]) - "as your letter of recommendation told me" (Muir, p. 147);

- "itzt bin ikh luft bay ir" (p. 183) - "Jetzt bin ich der Abwesende" (p. 246, here Kafka could have but does not use the colloquial "jetzt bin ich Luft für sie" [now I am air for her]) "Now it's my turn to be treated as if I were absent" (Muir, p. 181 );

- "mit leib un lebn" (p. 190) - again, the same expression exists in German but Kafka uses the more formal "ganz hingegeben" ( $p$. 256) - "devoting myself singlemindedly" (Muir, p. 188). 
readers not familiar with the culture. For instance, the Yiddish translation refers to Josef K.'s uncle as "der dibuk fun dorf" (p. 97) [the evil spirit from the village]. This reference to the $d y b b u k$, an evil spirit from Jewish folklore, has little in common with the English "a ghost from the past" (p. 92), which rather reminds one of Charles Dickens' Christmas Carol. As for the original German, the expression "das Gespenst vom Lande" (p. 119) [the ghost from the country] is quite neutral and not specifically Jewish. However, calling the uncle a $d y b b u k$ is not entirely far fetched: in the original German the uncle is said to enter suddenly and unexpectedly, and he immediately assumes control over K. - thus, he functions like an evil spirit, acting not unlike a dybbuk in Jewish folklore, which Kafka was indeed familiar with through his reading of the Yiddish writers Mendele and Peretz.

Moreover, the Yiddish translation alludes to the concept of metempsychosis, gilgul, in Jewish folkore. The accused Block's multiple transformations which take place in only one hour are rendered as "vos far a gilgulim er is dos shoyn durkhgegangen in der eyn-eyntsiker sho!" (p. 194) [what transformations he has already undergone in that one hour!]. The concept of metamorphosis, in particular animal metamorphosis, is a very common motif in folk and hasidic stories; according to Gershom Scholem (1961) it is an "integral part of Jewish popular belief and Jewish folklore" (p. 283). However, at first sight there is not much in the original German to suggest these cultural associations: Kafka does not even use the imagistic term "Verwandlung" [transformation] but the very neutral noun "Veränderungen" (p. 262) [changes]. What is characteristic about Block's "changes," though, is that he is ultimately reduced to an animal level: he becomes "der Hund des Advokaten" (265) [the lawyer's dog]. Thus, again it is not so far-fetched for the Yiddish translator to establish this particular cultural context by alluding to animal metamorphosis in Jewish folklore, a concept which Kafka, unlike many of his readers, was quite familiar with. Right away, then, the choice of vocabulary in the Yiddish translation places the text within a culturally specific literary genre and suggests an alternate "Jewish" reading within a populist-hasidic framework, with its associations of transgression, 
punishment and continual striving for redemption. The recurring motifs of metamorphosis, trial and redemption in many of Kafka's texts take on a different meaning if they are understood within the framework of the populist-hasidic folk genre: such cultural allusions are most obvious not only in the trials of Josef K. and others in Der Proce $\beta$ but in those of Karl Rossmann in Der Verschollene (Amerika) as well and particularly in the trials of Gregor Samsa in "Die Verwandlung" ["The Metamorphosis"] (Bruce 1987). ${ }^{10}$ Quite appropriately, in the afterword, Ravitsh translates the title of Kafka's "Die Verwandlung" as "der gilgul" (p. 237).

\section{Gesture, Word Games, and Humour in Kafka}

What is most significant about Ravitch's translation is its sensitivity to gesture, word games and humour in Kafka: many such scenes are highlighted in the Yiddish but have generally received far too little attention from critics. As before, where the English translation ignores or misses gesture, the Yiddish "corrects" these representations. For instance, the German "Leute die sich dort in Kleidern streckten" (p. 56) [people who were stretching themselves in their clothes] is translated in the English as "others who were resting there in their clothes" (p. 36). "Strecken" is here interpreted in the sense of "sich ausstrecken" [to lie down in order to rest]. What is meant here, though, is "strecken" in the sense of "stretching" which is reproduced in the Yiddish: "menshen in die malbushim vos tsien a bisl oys di glider" (p. 47) [people in their clothes who are stretching their limbs a bit]. This and many other examples show that the Yiddish translator is careful to highlight the imagistic and gestural quality of Kafka's text.

10. The first scholar, to my knowledge, who pointed out the relationship of Gregor's metamorphosis to the Jewish folk and mystic tradition was Maurice Blanchot in 1952: "That the theme of "The Metamorphosis" (as well as the obsessing fictions of animality) is a reminiscence, an allusion to the cabalistic metempsychosis, can well be imagined [...]" (p. 218, note 5). More recent references can be found in Grözinger, ed. (1987), pp. 101 and 116. 
The Yiddish translation also supplements imagistic and gestural elements whenever they are implicit in the source text. To be sure, Yiddish is generally more imagistic than German. For instance, the plain German "K. nickte" (p. 216) [K. nodded] is rendered as "K. hot a shokl geton mitn kop oyf yo" (p. 161) [K. shook his head in a way which meant 'yes']. But in the following example the Yiddish translation goes even further and embellishes on the German source text: thus, "Sie machte [...] einen Rundgang durch das Zimmer" (p. 41) - "she made a tour of the room" (Muir, p. 24), in the Yiddish becomes "[zi] hot zikh a drey geton arum un arum dem tsimer" (pp. 37-38) [she turned herself around and around in the room]. In the following case as well, the Yiddish translation "interprets" or "fills in" gestures that are only intimated in the source text: "[...] der her hot a makh geton mit der hant, vi eyner zogt: far vos nisht" (p. 77) [the man made a gesture with his hand as if to say: why not]. The more formal formulation in the original German "der Herr gab mit einer Handbewegung die Erlaubnis" (p. 102) [the man gave his permission with a gesture of his hand] contains no interpretation of the gesture, nor does the English translation, "the gentleman waved his hand to indicate permission" (p. 69).

More than that, the translator brings out the theatrical element in many scenes and thereby makes explicit the humorous potential which is implicit in the German. The context in the following is merchant Block, sympathizing with $\mathrm{K}$. and giving him advice:

[...] ich habe es selbst erfahren, daß man am liebsten alles wegwerfen, sich zuhause ins Bett legen und von nichts mehr hören wollte. Das wäre aber natürlich wieder das Dümmste, auch hätte man im Bett nicht lange Ruhe (p. 243). [I know this myself, this feeling that one would rather throw everything away, lie down at home in bed and close one's eyes to the world. But that again would be the silliest thing, on top of that one would not last very long in bed].

The difference in translation concerns the warning as to why one should not take oneself to bed. In the English we hear: "And of course that would be stupider still, for even in bed one wouldn't 
find peace" (p. 179). The English translation interprets "Ruhe" as "peace," implying "peace of mind," i.e. K's anguish will not let him sleep. The Yiddish on the contrary understands the colloquial expression "Keine Ruhe haben" [to be restless, nervous] and renders the whole scene in a humorous fashion by concentrating, like the German original, on the possible length of time which one could last in bed:

volt ober grod aza banemung geven di same greste narishkeyt; un vi lang volt men den gekent aynlign azoy in bet (p. 179) [but this would be the silliest solution; and how long can one lie in bed like this anyway]

Going to bed here is dismissed because it is kind of silly, a "narishkayt." The Yiddish translator evidently decided to shift away from K.'s existential despair which will not let him sleep in the English translation and instead replaced the serious English formulation with a joke about the length of time one can actually spend in bed. The whole scene in Yiddish ends on a very humorous tone when Block concludes, "nu, bin ikh gants poshet gegangen tsu di vinkl-atvokatn" (p. 179) [so that's when I quickly went to see the lawyers].

Highlighting the gestural, humorous qualities of many scenes in Kafka's texts should not be passed off easily. As early as 1934 Walter Benjamin pointed to the significance which lies

noch in der unscheinbarsten Geste. Vielfach und oft aus sonderbarem Anlaß klatschen Kafkas Figuren in die Hände. Einmal jedoch wird beiläufig gesagt, daß diese Hände "eigentlich Dampfhämmer" sind (p. 10) [significance lies "even in the seemingly most insignificant gesture. Often, and frequently the result of a strange occurrence, Kafka's figures clap their hands. At one point it is mentioned in passing that these hands are "really steam-hammers"].

Here we have a similar curious combination of gesture, imagery and humour. However, Kafka's imagistic playfulness hardly comes across in the English translation, as the following example will 
show: "'Let me alone, damn you,' cried K." (p. 9). The Muirs chose to translate the German "zum Teufel" (lit.: [go] to the devil; fig.: damn you) figuratively. But Kafka here plays on both meanings, and a literal translation "to the devil" (p. 18) would have been more appropriate because Kafka only a moment later takes the German phrasing "laßt mich, zum Teufel" (p. 18) [leave me alone, go to the devil/damn you] literally when a man suddenly appears on the scene who has a "rötlichen Spitzbart" (p. 20) [pointed red beard]. This is a technique which Kafka uses frequently, namely the "translation of mental images, particularly those enshrined in common idiom, into literal fact" (Pasley, 1977, p. 190). ${ }^{11}$ In addition, as Theodor W. Adorno (1955) has remarked insightfully, this practice is not devoid of humour: "Gelegentlich wird die Wörtlichkeit bis zum Assoziationswitz getrieben" (p. 306) [at times literal formulations even have a humorous dimension by virtue of their associative quality]. This is particularly obvious in the previous example where the "devil" suddenly appears in person. The English translation severs the connection between the expression "go to the devil" and the actual appearance of a "man with a reddish, pointed beard" ( $\mathrm{p}$. 10) by translating the figurative meaning, the expletive "damn you" (p. 9). But Kafka's technique of taking metaphorical expressions literally is retained in the Yiddish translation. Here K.'s exclamation, "lost mikh, op tsu al di rukhes!" (p. 24) [leave me alone, go to the devil] prepares for the sudden appearance soon after of the "devil" in person, in the form of a man with a "roytlekh shpitsbertl" (p. 25) - another dybbuk! It is through this careful attention to "Wörtlichkeit" [literal meaning] that the Yiddish translation succeeds

11. Pasley further points out how "The story 'The Bridge' (1916) furnishes a good example of an image thus drawn from metaphorical usage 'to bridge' (überbrücken). To represent a man acting as a real bridge is essentially a joking procedure [...]" (p. 189). Cf. also Binder (1992, pp. 99-104). However, this is only one of many techniques Kafka employs. In regard to "The Metamorphosis," for instance, Stanley Corngold (1970) shows that the "literalization of the metaphor is actually [not] accomplished" and speaks instead of Kafka's "distortion of the metaphor" (p. 98). 
in bringing out not only the picturesque and imagistic quality of Kafka's text but also its playfulness.

Additional support for the humorous and gestural reading of Der Proce $\beta$ is provided by the painter Yossl Bergner who has represented some of the funniest scenes in the form of illustrations. One drawing depicts a large hole in the floor of the law offices which makes lawyers trip, while the accused beneath them, sitting on benches, are looking up to the ceiling at a leg which is sticking out and which looks as if it is about to crush those underneath (p. 118) [Figure 1]. Another drawing depicts a scene where an official of the court is pushing all lawyers down the stairs, and we see them falling over each other and coming to rest on top of each other in a big heap (p. 160). For the most part, the captions under these pictures are taken directly from the Yiddish translation except for one instance where the translator deliberately chooses not the literal Yiddish translation from the German but rather opts for the English translation. The drawing in question depicts the painter Titorelli whirling a little woman, a hunchback, around himself (p. 181) [Figure 2].

The German original at this point states: "[...] der Maler jagte hinter ihr her, packte sie bei den Röcken, wirbelte sie einmal um sich herum..." (191; my emphasis) [the painter chased the woman, grabbed her by her skirts and whirled her around himself once]. However, the Yiddish caption under the drawing reads: "[...] er is nokhgelofn nokh ir, un arumgedreyt arum zayn kop" (p. 181) [he ran after her and whirled her around his head]. On the one hand, the Yiddish translation here deliberately draws on the English translation, which had already filled in this gesture by stressing the painter's head as the point of balance: he "whirled her once round his head" (p. 143). But the English retains the German "once," whereas the Yiddish caption under the picture suggests that this gesture is repeated more than once. Since the Yiddish translation of this passage earlier on is absolutely literal and identical with the German original - "er hot zikh ober tekef nokhgeyogt nokh ir, hot zi ongekhapt bay di kleydlekh, hot zi virbldik eyn mol a drey geton 


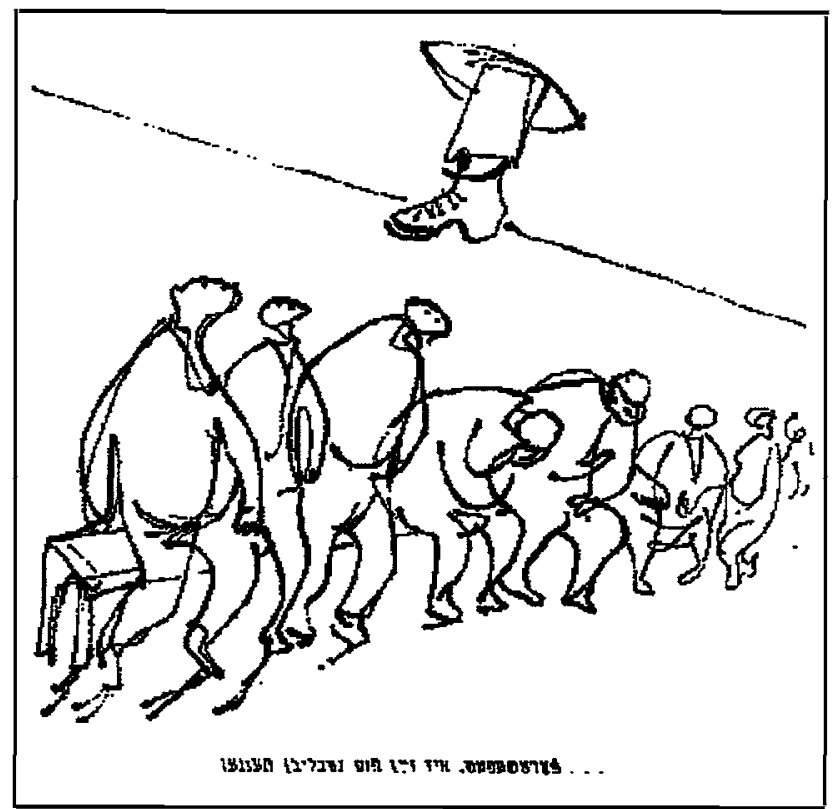

Figure 1

arum zikh [...]" (p. 145; my emphasis, "one time") - the translator's resorting to the English translation for the caption again reveals his deliberate attempt to bring out the gestural quality or humorous potential inherent in many scenes in the source text. It is this emphasis on the gestural, humorous dimension in Kafka's text which makes the Yiddish translation a welcome counter-translation to the common "serious" readings of Kafka.

\section{Conclusion}

These humorous scenes are indeed in the source text, but they are all too often over-looked by critics. As Malcolm Pasley (1977) remarks:

Kafka's covert jokes and puns are as much disputed as his riddling devices to which they are related. It is often thought derogatory and impudent even to suggest their presence in such "serious writing." And yet if we ignore the playful spirit which 


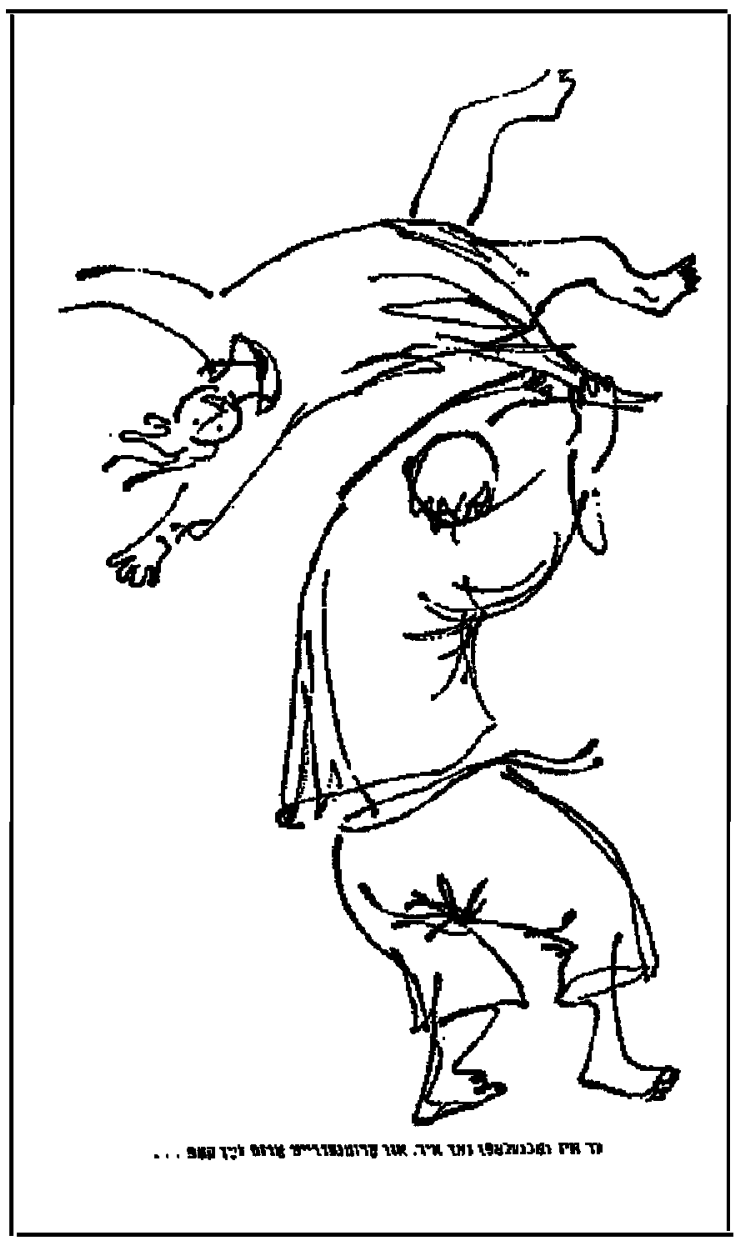

Figure 2

informs many of his stories, we miss their special flavor [...]. This playfulness is not only compatible with the highest seriousness, but it is actually inseparable from it (p. 189).

As a matter of fact, Ravitch's attempt to present a more humorous, gestural and near theatrical reading of Kafka in his translation accords with Max Brod's comment on the presence of humour in Der Prozeß. Though it has become fashionable to dismiss Brod's 
admittedly ideological reading of Kafka, his personal memories cannot all be unreliable. Brod remembers how he and his friends were laughing when Kafka read from his own work:

Wenn Kafka selbst vorlas, wurde dieser Humor besonders deutlich. So zum Beispiel lachten wir Freunde ganz unbändig, als er uns das erste Kapitel des 'Prozess' zu Gehör brachte. Er selbst lachte so sehr, daß er weilchenweise nicht weiterlesen konnte. Erstaunlich genug, wenn man den fürchterlichen Ernst des Kapitels bedenkt. Aber es war so $(1954$, p. 156) [When Kafka read from his works this humour became particularly obvious. Thus we all laughed our heads off when he read out to us friends the first chapter of The Trial. He himself laughed so much that he couldn't read on from time to time. This is incredible if one considers the profound seriousness of that chapter. But that's what it was like]

Let us, as a final example, consider the ominous scene in the cathedral at the end of the novel, when Josef $\mathrm{K}$. is slinking away from the priest, everything is dead silent, only the walls are echoing his footsteps - the moment just before the priest makes him stop by calling out loudly "Josef K." The Yiddish translation once again not only emphasizes gesture but also interprets the scene in a humorous fashion. This is the situation: the priest is standing on the pulpit, leaning over a little, with his hands holding onto the railing, all the time without movement: as the German says, "[er] blickte ohne den Kopf zu rühren umher" (p. 285). The English translation is literal, "[he was] looking around him without moving his head" (p. 208). The Yiddish translation, however, goes a step further by emphasizing "Wörtlichkeit," by highlighting the literal connotations and associations, and brings out what is implicit in each word: first, the prefix in "umherblicken" [to look around, my emphasis] suggests spatial and temporal dimensions; second, it implies a movement of the eyes. Finally, the whole description of moving one's eyes in order to look around but "ohne den Kopf zu bewegen" [without moving one's head] is another one of those curious theatrical gestures that Walter Benjamin drew attention to. The Yiddish translation brings out the humour in this scene by emphasizing all three elements, the temporal and spatial dimensions, the movement 
of the eyes, and the immobility of the head: "[...] azoy is er geshtanen a tsayt un gekukt ahin un aher - nisht a rir tuendik dem kop zaynem" (p. 213) [thus he stood there for a while and looked around in all directions - while he did not move his head]. Any visualization of this scene or any acting it out would produce laughter in the audience.

Little gestures, humorous theatrical scenes - these are elements that are frequently ignored not only by English readers but by German readers as well. The gestural-theatrical quality of Kafka's texts often rests on metaphorical ambiguity and word games. At times figurative expressions are taken literally and even come to life, such as the expletive "zum Teufel" [lit.: to the devil; fig.: damn it]. Other literary creations, such as Gregor Samsa in "Die Verwandlung" [The Metamorphosis] or "Odradek" in Kafka's story "Die Sorge des Hausvaters" ["Cares of a Family Man"] are more ambiguous signifiers without a clearly identifiable signified. However, they too play out their not altogether humourless existence in the spaces between words and their various tenuous links and connotations. ${ }^{12}$ Ravitch's Yiddish translation recaptures such

12. In terms of linguistic ambiguity, the function of Odradek is just as indeterminate as that of Gregor Samsa where Corngold (1970) speaks of "an indeterminacy sheerly negative" (p. 99). But if, as Corngold argues, "the generative principle of Kafka's fiction" is indeed "a metamorphosis of the function of language" (p. 99) then this function could be alternately both positive and negative. The at times humorous representation of Gregor's (Bruce, pp. 12-15) as well as Odradek's predicament might allow for the coexistence of both readings. Odradek laughs when he states he has no fixed home, "Unbestimmter Wohnsitz." His laughter is thus associated with the very indeterminacy of his existence, and the narrator uses his laughter to further play with connotations and associations,"es ist aber nur ein Lachen, wie man es ohne Lungen hervorbringen kann. Es klingt etwa so, wie das Rascheln in gefallenen Blättern" (Kafka, 1970, p. 140) [but it is only a laughter which one can produce without any lungs. It sounds a little like the rustling in fallen leaves]. 
linguistic possibilities in Der Proce $\beta$ and thereby challenges the traditional kafkaesque readings.

University of Alberta

\section{References}

ADORNO, Theodor W. (1955). Prismen. Kulturkritik und Gesellschaft. Frankfurt/M., Suhrkamp, 1976.

NICOLAS Baudy (1950). "Entretiens avec Dora Dymant. Compagne de Kafka." Evidences II(8), pp. 21-25.

BENJAMIN, Walter (1934). "Franz Kafka. Zur zehnten Wiederkehr seines Todestages." Benjamin über Kafka. Ed. H. Schweppenhäuser. Frankfurt/M., Suhrkamp, 1981, pp. 9-38.

BENNETT, Arnold (1987). "Kafka's Dick." Two Kafka Plays. London, Forelake Limited, pp. 3-71.

BINDER, Hartmut (1979). Ed. Kafka Handbuch. Bd. 2: Das Werk und seine Wirkung. Stuttgart, Alfred Kröner Verlag.

(1992). "Common Sayings and Expressions in Kafka." Trans. by Donald \& Iris Bruce. TTR, V(2), pp. 41-105.

BLANCHOT, Maurice (1952). "The Diaries: The Exigency of the Work of Art." Trans. Lyall H. Powers. Franz Kafka Today. Eds. A. Flores \& H. Swander. Madison, Wis., University of Wisconsin, 1964, pp. 195-220.

BROD, Max (1954). Über Franz Kafka. Frankfurt, Fischer, 1977.

BRUCE, Iris (1987). "Kafka's Metamorphosis: Folklore, Hasidism and the Jewish Tradition," Journal of the Kafka Society of America XI(1/2), pp. 9-27. 
CORNGOLD, Stanley (1977). "Recent Kafka Criticism." The Kafka Debate. Ed. A. Flores. New York, Gordian Press, pp. 60-73.

(1970). "Kafka's Die Verwandlung: Metamorphosis of the Metaphor." Mosaic III(4), pp. 91-106.

CRAWFORD, Deborah (1973). Franz Kafka. Man Out of Step. New York, Crown.

DELEUZE, Gilles and Felix GUATTARI (1986). Kafka: Toward a Minor Literature. Trans. from the French (published in 1975) by Dana Polan. Minneapolis, University of Minnesota Press.

DEMMER, Jürgen (1973). Franz Kafka, der Dichter der Selbstreflexion. München, W. Fink.

EMRICH, Wilhelm (1958). Franz Kafka. Frankfurt, Athenaion.

Encyclopaedia Judaica (1971) 4: 618 [Yossl Bergner]; 13: 1585-86 [Melech Ravitch]. Jerusalem, Keter Publishing House.

FRIEDMAN, Maurice (1967). "The Dialogue with the Absurd: The Later Camus and Franz Kafka; Elie Wiesel and the Modern Job." To Deny Our Nothingness: Contemporary Images of Man. New York, Delacorte, pp. 335-354.

GOLOMB, Jacob (1985). "Kafka's Existential Metamorphosis: From Kierkegaard to Nietzsche and Beyond." Clio: A Journal of Literature, History, and the Philosophy of History, XIV(3), pp. 271286.

GOODMAN, Paul (1947). Kafka's Prayer. New York, The Vanguard Press.

HEIDSIECK, Arnold (1983). "Franz Kafka: Outsider in His Own World." The Anxious Subject: Nightmares and Daymares in Literature and Film. Ed. Moshe Lazar. Malibu, Undena, pp. 169181. 
HOWE, Irving; Wisse, Ruth R.; Shmeruk, Khone (1987). Eds. The Penguin Book of Modern Yiddish Verse. Harmondsworth, Penguin.

JAKOB, Dieter (1970). "Das Kafka-Bild in England, 1928-1966." Oxford German Studies 5, pp. 90-143.

KAFKA, Franz (1990). Der Proceß. Roman in der Fassung der Handschrift. Frankfurt/M., S. Fischer Verlag.

(1988). The Trial. Trans. by Edwin \& Willa Muir. Revised, and with additional material translated by E.M. Butler. New York, Schocken.

(1975). Briefe. 1902-1924. Ed. Max Brod. Frankfurt, Fischer.

Frankfurt, Fischer.

(1970). Sämtliche Erzählungen. Ed. Paul Raabe. (1966). Der Prozes. Trans. into Yiddish by Melech Ravitch. Illustrations by Yossl Bergner. New York, Der Kval.

MADISON, Charles A. (1968). Yiddish Literature. Its Scope and Major Writers. New York, Schocken.

PASLEY, Malcolm (1977). "Semi-Private Games." The Kafka Debate. Ed. Angel Flores. New York, Gordian Press, pp. 188-205.

PAWEL, Ernst (1987). "Franz Kafkas Judentum." Kafka und das Judentum. Eds. K. E. Grözinger, et al. Frankfurt, Jüdischer Verlag bei Athenäum, pp. 253-258.

ROBERT, Marthe (1979). As Lonely as Franz Kafka. Trans. from the French by Ralph Mannheim. New York, Schocken, 1986.

SCHOEPS, Hans Joachim (1951). "Theologische Motive in der Dichtung Franz Kafkas." Die Neue Rundschau 62, pp. 21-37. 
SCHOLEM, Gershom (1967). "Deutsche und Juden." Deutsche und Juden. Beiträge von Nahum Goldmann, Gershom Scholem, Golo Mann, Salo W. Baron, Eugen Gerstenmaier und Karl Jaspers. Frankfurt, Suhrkamp Verlag, pp. 21-48.

Schocken.

(1961). Major Trends in Jewish Mysticism. New York,

TIEFENBRUN, Ruth (1973). Moment of Torment. Carbondale \& Edwardsville, Southern Illinois University Press.

WHITMAN, Ruth, ed. \& trans. (1966). An Anthology of Modern Yiddish Poetry [Bilingual Edition]. N. p., Education Dept. of the Workmen's Circle, 1979.

ZILBERTSVAYG, Zalmen (1968). "Frants Kafka un dos Yidishe Teater" [Franz Kafka and the Yiddish Theatre]. Yiddishe Kultur XXX(1), pp. 38-43, 56.

\begin{abstract}
Der Proce $\beta$ in Yiddish, or the Importance of being Humorous - The article argues for a "humorous" Franz Kafka rather than a kafkaesque one and criticizes the "Kafka myth" which cristallized after WWII and emphasized foremost Kafka's existential anguish. Even before the war Max Brod as well as Walter Benjamin recognized the humorous dimension in Kafka's texts, much of which lies in word plays and gesture; otherwise, the humour in Kafka was largely ignored, especially after WWII. The focus in this article is on English, German and Yiddish cultural contexts and ideologies which have determined different readings/ translations of Kafka's texts. In particular, the article compares the pre-war English translation of Der Proce $\beta$ by Edwin and Willa Muir, which contributes to the "Kafka myth," with a post-war Yiddish translation by Melech Ravitch, which highlights the novel's humorous qualities. Not only does the Yiddish translation place Kafka's novel within a culturally specific literary genre and suggest an alternate "Jewish" reading of the text; by drawing on both the English translation and the German original, Ravitch also "corrects" the anguish laden "Kafka myth" and constitutes a challenge to the rather humourless genre of the kafkaesque so widespread still in contemporary English and German speaking cultures.
\end{abstract}


RÉSUMÉ: Le Procès en yiddish ou l'importance d'être humoristique L'auteure met en lumière le Kafka humoristique - et non kafkaesque - et critique le «mythe Kafka» qui s'est constitué après la Seconde Guerre mondiale, centré surtout sur l'angoisse existentielle chez Kafka. Bien avant la guerre, Max Brod ainsi que Walter Benjamin reconnurent la dimension humoristique des textes de Kafka, dont l'essentiel se trouve dans les jeux de mots et les gestes; en dehors de ces auteurs, l'humour chez Kafka restait inaperçu. Le présent article met l'accent sur les contextes culturels et idéologiques anglais, allemand et yiddish qui ont déterminé des lectures/traductions disparates de ses textes. L'article établit surtout une comparaison entre la traduction d'avant-guerre du Procès par Edwin et Willa Muir, qui contribua au «mythe Kafka», et la traduction yiddish d'après-guerre de Melech Ravitch, laquelle souligna les qualités humoristiques du roman. D'une part, la traduction yiddish situe le roman de Kafka dans un genre littéraire qui est culturellement spécifique en même temps qu'elle suggère une lecture «juive» alternative du texte; mais, d'autre part, se fondant sur la traduction anglaise et la version allemande originale, Ravitsch «corrige» aussi le «mythe» du Kafka angoissé et constitue un défi au genre assez morne du kafkaesque qui demeure si répandu dans les cultures de langue anglaise et allemande contemporaines. 